\title{
IMPLEMENTATION OF EXISTING INTERNATIONAL LEGAL INSTRUMENTS FOR CONSERVATION AND SUSTAINABLE USES OF MARINE BIODIVERSITY IN AREAS BEYOND NATIONAL JURISDICTION: A CASE STUDY OF THE OSPAR CONVENTION
}

\author{
LINDSAY RYAN VALERIO \\ Predoctoral student \\ Universitat Rovira i Virgili \\ linry25@hotmail.com
}

Received: July 20th 2012 / Accepted: October 10th 2012

\begin{abstract}
The states of the world face the new challenge of attempting to prevent the global loss of marine biodiversity by protecting the $64 \%$ of the surface area of the oceans that lies beyond national jurisdiction. With this aim, various regional agreements have been negotiated to commit states to set up representative networks of marine protected areas (MPAs). The aim of this note is to explain how it was possible to designate six MPAs in the high sea under the OSPAR Convention and some of the challenges this process raised.
\end{abstract}

RESUM: Els estats del món afronten nous reptes per aturar la pèrdua global de biodiversitat marina, mitjançant la protecció del $64 \%$ de la superfície oceànica fora de jurisdicció nacional. Amb aquests objectius, s'han negociat diversos acords regionals per comprometre els estats en l'establiment de xarxes representatives d'àrees marines protegides (AMP). Com va ser possible la designació de sis AMP en alta mar sota la Convenció OSPAR i alguns reptes relacionats amb això són l'objecte d'aquesta nota.

RESUMEN: Los estados del mundo enfrentan nuevos retos para detener la pérdida global de la biodiversidad marina, a través de la protección del 64\% del océano ubicado en las áreas fuera de la jurisdicción nacional. Con este objetivo, diversos acuerdos 
regionales se han negociado para comprometer a los estados en el establecimiento de redes representativas de áreas marinas protegidas (AMP). Cómo fue posible la designación de seis áreas marinas protegidas en alta mar en el marco del Convenio OSPAR y algunos de los retos relacionados se examinarán en esta nota.

KEYWORDS: Conservation and sustainable use of marine biodiversity — marine protected areas - oceans beyond national jurisdiction - OSPAR Convention.

PARAULES CLAU: Conservació i ús sostenible de la biodiversitat marina — àrees marines protegides - superfície oceànica fora de jurisdicció nacional — Convenció OSPAR.

PALABRAS CLAVE: Conservación y uso sostenible de la biodiversidad marina áreas marinas protegidas - superficie fuera de la jurisdicción nacional — Convención OSPAR.

Summary: I. Introduction. II. Establishing an international legal framework for conservation and sustainable uses of marine biodiversity beyond national jurisdiction. 1. Legal Framework for regulating Marine Protected Areas beyond National Jurisdiction. III. Implementation of the legal instruments for establishing Marine Protected Areas beyond National Jurisdiction: A case of study of the OSPAR Convention. 1. The Convention for the Protection of the Marine Environment of the North-East Atlantic. 2. The designation of the OSPAR network of marine protected areas in the high sea. IV. Final considerations. V. Bibliography.

\section{INTRODUCTION}

The States of the world face new challenges if they are to prevent the global loss of marine and coastal biodiversity. ${ }^{1}$ They need to increase efforts to protect $64 \%$ of the ocean located in areas beyond national jurisdiction (hereinafter, ABNJ), a goal that can only be achieved through public international law and regional cooperation. ${ }^{2}$

\footnotetext{
1 For threats to ABNJ see WARNER R., Protecting the Ocean beyond National Jurisdiction: Strengthening the International Law Framework, Martinus Nijhoff, Leiden/Boston, 2009, pp. 14-26.

${ }^{2}$ KIMBALL, L., The International Legal Regime of the High Seas and the Seabed Beyond the Limits of National Jurisdiction and Options for Cooperation for the establishment of Marine Protected Areas (MPAs) in Marine Areas Beyond the Limits of National Jurisdiction, Secretariat of the Convention on Biological Diversity, Montreal, Technical Series no. 19, 2005, iii.
} 
For this reason an increasing number of international instruments are still calling for the use of area-based management tools, in particular MPAs, ${ }^{3}$ for the protection and preservation of marine biodiversity and the sustainable use of the oceans' resources. The MPAs will help to reduce the decline in ocean biomass and the risk of fisheries collapse and will improve the negative impacts of human activities such as cable laying or deep sea bottom trawling. ${ }^{4}$

With these aims, a collage of regional agreements has been negotiated around the globe to commit States to protecting their offshore marine environments by regulating various sources of marine pollution and establishing MPAs. ${ }^{5}$ The geographical scope of many of them is limited to waters within national jurisdiction, while a few others provide for conservation and the sustainable use of marine biodiversity in ABNJ based on framework conventions. An example of the latter is the designation of MPAs in the ABNJ of the North East Atlantic region by the OSPAR Convention (see below). ${ }^{6}$

In this regard, international environmental law has developed rapidly since the 1972 United Nations Conference on Human Environment (Stockholm Conference), ${ }^{7}$ and awareness has been raised about the seriousness of environmental degradation and the need for extensive cooperation among nations if it is to be combatted. Subsequently, the 1992 United Nations Conference on Environment and Development (UNCED) ${ }^{8}$ adopted one of the important treaties - the Convention on Biological Diversity (CBD) ${ }^{9}-$ which

\footnotetext{
${ }^{3}$ Definition of MPA “ $(\ldots)$ any defined area within or adjacent to the marine environment, together with its overlying waters and associated flora, fauna, and historical and cultural features, which has been reserved by legislation or other effective means, including custom, with the effect that its marine and/or coastal biodiversity enjoys a higher level of protection than its surroundings' Report of the Ad Hoc Technical Expert Group on Marine and Coastal Protected Areas, UNEP/CBD/SBSTTA/8/INF/7, Montreal, 13 February 2003, paras 29-31 and 62-63. Available online: $<$ http:/www.cbd.int/doc/meetings/sbstta/sbstta-08/information/sbstta-08-inf-07-en.pdf $>\quad$ accessed 25/05/2012.

${ }^{4}$ KIMBALL, L., “The International Legal Regime ..." cit.

5 SAND, P., Transnational Environmental Law: Lesson in Global Change, Kluwer Law International, The Hague, 1999, pp. 178-182.

6 TREVES, T.,"Regional Approaches to Protection of the Marine Environment" in Myron H. Nordquist and others, The Stockholm Declaration and the law of the Marine Environment, Kluwer Law International, The Hague, 2003, pp. 137-138.

${ }^{7}$ Report of the United Nations Conference on the Human Environment, Stockholm, 5-16 June 1972. UNDOC. A/CONF.48/14/Rev.I (1972), 11 ILM 1416.

${ }^{8}$ Report of the United Nations Conference on Environment and Development, Rio de Janeiro 3-14 June 1992. UNDOC. A/CONF.151/26/Rev.1 (Vol. 1- III), New York, 12 August 1993.

${ }^{9}$ Convention on Biological Diversity (CBD), Rio de Janeiro, 5 June 1992, in force 29 December 1993, UNTS vol. 1760, No. 30619, p. 79.
} 
have had considerable impact not only on the development of international environmental law, but also on economic development and trade relations. Also influential have been two non-binding documents issuing from UNCED: the Declaration of the Conferences (Rio Declaration) and the Agenda 21, a program of action setting out the measures required to protect and preserve the environment in the 21st century. ${ }^{10}$ Many of these instruments were strongly reaffirmed at the World Summit on Sustainable Development (WSSD) ${ }^{11}$ and have direct implication for the protection of the marine environment and the living resources of the sea.

During this period, we have also seen the parallel negotiation and entry into force of the United Nations Convention on the Law of the Sea 1982 (LOSC), ${ }^{12}$ which is an important legal framework for the world's oceans and seas, and unifies instruments related to biodiversity (such as the CBD), fisheries (such as the Food and Agriculture Organization, FAO), and sources of pollution (such as measures adopted in the context of the International Maritime Organization, IMO).

The purpose of this note is to provide an overview of the implementation of the existing international legal instruments for the conservation and sustainable uses of marine biodiversity BNJ. With this objective, brief mention is made of several policy initiatives that have been taken by the international community to establish MPAs as a global goal. The legal frameworks, in particular LOSC and CBD that regulate the MPA in ABNJ, are also discussed. The topic of the third part is how the OSPAR Convention is implementing these instruments at both the global and regional levels for the conservation and sustainable uses of marine biodiversity, specially creating the first network in the world of MPAs located in the high seas.

\footnotetext{
${ }^{10}$ The Rio Declaration 4 (1992) 31 ILM 874. For more information, see the UN Department of Economic and Social Development, Sustainable Development, website at <www.un.org/esa/sustdev>.

${ }^{11}$ United Nations Report of the World Summit on Sustainable Development (WSSD) Johannesburg, South Africa, 26 August to 4 September 2002. UNDOC. A/CONF.199/20, New York, 4 September 2002.

${ }^{12}$ United National Convention on Law of the Sea (LOSC.), Montego Bay, 10 December 1982, in force 16 November 1994, UNTS vol. 1833, No. 31363, p. 3.
} 


\section{ESTABLISHING AN INTERNATIONAL LEGAL FRAMEWORK FOR CONSERVATION AND SUSTAINABLE USES OF MARINE BIODIVERSITY BEYOND NATIONAL JURISDICTION}

\section{General observations}

The establishment of MPAs has been a priority for global marine conservation. In fact, the first international commitments to a global system of MPAs, which include the high seas, was the resolution adopted at the IUCN General Assembly in $1988 .{ }^{13}$ Nevertheless, there have been various other commitments this century. Firstly, in 2002 the States at the World Summit on Sustainable Development (WSSD) ${ }^{14}$ adopted further commitments to reduce the rate of biodiversity loss by 2010 and also set up MPAs in accordance with international law, including representative networks by $2012 .{ }^{15}$

Subsequently to this commitment, as the global political forum in all matters of the ocean including the implementation of the UNCLOS, ${ }^{16}$ the United Nations General Assembly (UNGA) reaffirmed the commitment of the States to developing and facilitating the use of a variety of approaches and tools for conserving and managing vulnerable marine ecosystem by 2012 , with special attention to ABNJ. ${ }^{17}$

In relation to the UNGA and its role, mention should be made of the work of the Ad Hoc Open-Ended Informal Working Group, ${ }^{18}$ which is currently dealing with the process to ensure that the existing legal framework under LOSC effectively addresses conservation and the sustainable use of marine biodiversity in ABNJ. ${ }^{19}$ On this issue, it should be pointed out that a proposal has been made for a new implementing agreement

13 The 17th Session of the General Assembly of IUCN, San José, Costa Rica, 1-10 February 1988. Resolutions and Recommendations No. 17.38 "Protection of the coastal and marine environment", pp. 1718. Available online $<$ http://cmsdata.iucn.org/downloads/resolutions_recommendation_en.pdf $>$, accessed $28 / 5 / 2012$.

14 Johannesburg Plan of Implementation, cit, para. 32 (c). Available online http://www.johannesburgsummit.org/html/documents/summit_docs/131302_wssd_report_reissued.pdf accessed 28/5/2012.

${ }^{15}$ According to Chapter 17 of Agenda 21 para.17.46, 17.86 and 17.115. Available online $<$ http://www.un.org/esa/dsd/agenda21/res_agenda21_17.shtml > accessed 28/5/2012.

${ }^{16}$ Oceans and the Law of the Sea (General Assembly Resolution 57/141, 12 December 2002), paras 5153. See, ARDRON, J., et al, "Marine Spatial Planning in the High Sea”, Marine Policy, 32, 2008, p. 835.

${ }^{17}$ Oceans and the Law of the Sea (General Assembly Resolution 60/30, 29 November 2005); Oceans and the Law of the Sea (General Assembly Resolution 63/111, 5 December 2008); Oceans and the Law of the Sea (General Assembly Resolution 66/231, 24 December 2011), paras 165-178.

${ }^{18}$ Oceans and the Law of the Sea (General Assembly Resolution 59/24, 17 November 2004), para 73.

${ }^{19}$ General Assembly Resolution A/66/231, cit, paras. 166-168. 
to $\mathrm{UNCLOS},{ }^{20}$ which hopefully can provide a vehicle for implementing the ecosystem and precautionary approaches to high seas management, including MPA and Marine Spatial Planning. ${ }^{21}$

A final global commitment assumed in 2012, derived from the Conference of the Parties (COP) to the CBD and in accordance with the Jakarta Mandate, ${ }^{22}$ was to develop marine and coastal protected areas (MCPAs) including representative global networks in ABNJ. ${ }^{23}$ It was also agreed to submit 10 percent of the areas with particular importance for biodiversity to a regime of effective and equitable management and other area-based conservation measures by 2020 . This is known as the Aichi target. ${ }^{24}$

All these global commitments have generated multiple measures and some regional agreements sponsored by international organisations. Thus, these regulatory efforts have set strong expectations that global rules will be adopted to guide the future establishment of MPAs outside state jurisdictions. ${ }^{25}$ These rules could be drawn up on the basic requirements in LOSC and the CBD. However, there is a need for a legal instrument that can regulate the management and assessment of the environmental impacts of existing and emerging activities in waters BNJ. Only in this way will marine environmental protection, the sustainability of resources and the legitimate interests of the international community be properly harmonized and integrated. ${ }^{26}$

\footnotetext{
${ }^{20}$ General Assembly A/66/119, Letter dated 30 June 2011 from the Co-Chairs of the Ad Hoc Open-ended Informal Working Group to the President of the General Assembly, 30 June 2011, paras 23, 24, 29.

${ }^{21}$ ARDRON, J., "Marine Spatial ...” cit.

${ }^{22}$ Fourth Ordinary meeting of the Conference to the Parties to the Convention on Biological Diversity, Bratislava, Slovakia, 4-5 May 1998. Decision IV/5 work programme of marine and coastal biological diversity.

${ }^{23}$ Seventh meeting of the Conference to the Parties to the Convention on Biological Diversity, Kuala Lumpur, 9-20 and 27 February 2004. Decision VII/5 marine and coastal biodiversity, Doc. $\mathrm{UNEP} / \mathrm{CBD} / \mathrm{COP} / \mathrm{DEC} / \mathrm{VII} / 5,13$ April 2004. See paras 18, 19, 30 and 31. Available online $<$ http://www.cbd.int/doc/decisions/cop-07/cop-07-dec-05-en.pdf $>$ accessed 29/05/2012. For cooperation on establishing MPAs beyond national jurisdiction see: Eighth meeting of the Conference to the Parties to the Convention on Biological Diversity, Curitiba, Brazil 20-31 March 2006, Decision VIII/24 Protected Areas, Doc. UNEP/CBD/COP/DEC/VIII/24, 15 June 2006. See paras. 42-43.

${ }^{24}$ Tenth meeting of the Conference to the Parties to the Convention on Biological Diversity, Nagoya, Japan 18-29 October 2010, Decision X/2 Strategic Plan for Biodiversity 2011-2020 and Aichi Targets, $\mathrm{UNEP} / \mathrm{CBD} / \mathrm{COP} / 10 / 2 /, 29$ October 2010. See in particular, Annex, para. 13, targets 11. Available online $<$ http://www.cbd.int/doc/decisions/cop-10/cop-10-dec-02-en.pdf $>$ accessed 29/05/2012.

${ }^{25}$ Oceans and the Law of the Sea (General Assembly Resolution A 66/186), 25 July 2011, para 42.

${ }^{26}$ RAYFUSE R., and WARNER, R., "Securing a sustainable future for the oceans beyond national jurisdiction: the legal basis for an integrated cross- sectoral regime for the high seas governance for $21 \mathrm{st}$ century", The International Journal of Marine and Coastal Law 23, 2008, pp. 401 \& 402.
} 


\section{Legal Framework for regulating Marine Protected Areas beyond National}

\section{Jurisdiction}

\subsection{United Nations Convention on the Law of the Sea}

The 1982 United Nations Convention on the Law of the Sea (LOSC) provides the global legal framework for the seas and oceans, which promotes the sustainable use of their resources, the conservation of their living resources and the preservation of the marine environment, under the sovereignty ${ }^{27}$ and jurisdiction ${ }^{28}$ of its member States. It is complemented by two implementation agreements: namely, the Agreement relating to Part XII of $\operatorname{LOSC}^{29}$ and the Agreement for the Implementation of the provisions of LOSC relating to the conservation and management of straddling fish stock and highly migratory fish stocks. ${ }^{30}$

The Convention sets out States' rights ${ }^{31}$ and responsibilities, within and beyond the limits of national jurisdiction. ${ }^{32}$ In ABNJ that include the high sea, seabed and ocean floor, all States are under a general obligation to protect and preserve the marine environment. ${ }^{33}$ These duties include those necessary measures to protect and preserve rare or fragile ecosystems as well as the habitat of depleted, threatened or endangered species and other forms of marine life. ${ }^{34}$ In addition, all States have the duty to

\footnotetext{
${ }^{27}$ LOSC, Part I. Internal waters article 2-8. Part IV. Archipelagic water and Part II. Territorial sea.

${ }^{28}$ Id. Part V. EEZ and Continental Shelf established in conformity with the Convention, article 76.

${ }^{29} 1994$ Agreement for the Implementation of Part XII of the 1982 Law of the Sea Convention, 33 ILM 1309 (commonly referred to as "Part XI Implementing Agreement").

${ }^{30} 1995$ Agreement for the Implementation of the Provisions of United Nations Convention on the Law of the Sea of 10 December 1982, relating to the Conservation and Management of Straddling Fish Stock and Highly Migratory Fish Stocks, 4 August 1995, entered into force 11 December 2001, 24 ILM 1542 (1995).

${ }^{31}$ Coastal state's rights in respect of those of third States varies in relation to the legal condition of the waters. For example, in territorial sea States enjoy the right of innocent passage; in EEZ the third States enjoy freedom of navigation, overflight, laying of submarine cables and pipelines; on the high sea States have freedom of navigation, overflight, fishing, marine scientific research, construction of artificial islands, and laying of cables and pipelines. SCOVAZZI, T., "Marine protected areas on the high sea: some legal and policy considerations", International Journal of Marine and Coastal Law, vol. 19, No. 1, 2004 , p. 5.

${ }^{32}$ LONG, RONAN., "Review of the Legal Framework Applicable to Marine Protected Areas as a Tool for Ecosystem Conservation \& Fisheries Management", European Union, Specific Targeted Research Project PROTECT, Review of MPAs for Ecosystem Conservation \& Fisheries Management, Published by DIFRES Copenhagen 2006, p.17.

${ }^{33}$ LOSC, Part XII, article 192.

${ }^{34}$ Id. Article 194, para. 5. Also, the resolutions of the General Assembly 2004 (59/25), 2006 (61/105) and 2009 (64/72) have driven the urgency for the protection of vulnerable marine ecosystems.
} 
cooperate, both globally and regionally, in formulating and drafting international rules, standards and recommended practices and procedures to achieve these ends. ${ }^{35}$

In the case of the high sea, as remarked by the International Tribunal for the Law of the Sea (ITLOS) in the Order rendered on 3 December 2001, MOX Plant, "the duty to cooperate is a fundamental principle in the prevention of pollution of marine environment under Part XII of the Convention and general international law and that rights arise therefrom which the Tribunal may consider appropriate to preserve under article 290 of the Convention." 36 In this understanding, the international community as the trustee of the high sea may improve the coordination and cooperation with the global and regional bodies with sectoral responsibilities, such as the Conference of the Parties to the CBD, the Regional Fisheries Management Organizations (RFMOs), the IMO, the FAO and the regional agreements, which fulfill a relevant role in the protection and conservation of the marine environment. ${ }^{37}$

Furthermore, for the purpose of this note, the regime for the Continental Shelf deserves particular attention. This marine space "comprises the seabed and subsoil of the submarine areas that extend beyond the territorial sea throughout the natural prolongation of the land territory to the outer edge of the continental margin or to a distance of 200 nautical miles from the baselines where the outer edge of the continental margin does not extend up to that distance." $" 38$

In the Continental Shelf a coastal State has sovereign rights ${ }^{39}$ to explore and exploit its natural resources, which include the mineral and other non-living resources ${ }^{40}$ of the

\footnotetext{
${ }^{35}$ LOSC, article 197 and article 117. In other words the "obligation to cooperate" implies acting in good faith when entering into negotiations with the view to arrive at an agreement and to take into account the positions of other states.

${ }^{36}$ Tribunal of the Law for the Sea, The Mox Plant case (Ireland \&United Kingdom) Order LOSC, Part XII deals with "protection and preservation of the marine environment", 3 December 2001, para. 82. Available online: $<$ http://www.itlos.org/fileadmin/itlos/documents/cases/case_no_10/Order.03.12.01.E.pdf >, accessed 03/06/2012.

${ }^{37}$ RAYFUSE, R., and WARNER, R., “Securing a sustainable ...” cit, pp. 412-415.

${ }^{38}$ LOSC article 76(1). In accordance with the article the rights of the coastal State over the continental shelf are inherent and do not require any express proclamation, as does the EEZ.

${ }^{39}$ LOSC, Article 79- 81 and 246. All these Continental Shelf rights can also apply to their extended portions.

${ }^{40}$ While coastal States still have exclusive sovereign rights over non-living resources, article 82 requires the coastal states to make payments or contributions in kind to ISBA. As for other States, article 78 seeks to safeguard their interests.
} 
seabed and subsoil, together with living organisms belonging to sedentary species. ${ }^{41}$ These rights are "exclusive in the sense that if the coastal State does not explore the continental shelf or exploit its natural resources, no one may undertake these activities without the express consent of the coastal State." 42

The sovereign rights to conserve these resources are not expressly included but can be inferred from other provisions that control the pollution from activities that impact the Continental Shelf and from the conservation obligation arising in article 194 (5) LOSC. ${ }^{43}$ In other words, a coastal State also has the right to protect these resources from actions by other States that would damage them and without any doubt the potential interest in conflict arising from this proposal is significantly lessened with the application of a cooperative approach. ${ }^{44}$

All these rights apply to the extended portion of the Continental Shelf. However, to delimit this extended area, pursuant to LOSC, the coastal States must submit data to the Commission on the Limits of the Continental Shelf (CLCS) ${ }^{45}$ and until the CLCS has completed its work, the limits of the surface area will remain uncertain, thereby possibly creating a complex jurisdictional situation for offsetting up any MPAs in ABNJ. ${ }^{46}$

In summary, despite the fact that the LOSC does not include the specific terms of integration, precaution, ecosystem approaches or MPA networks, it provides a strong legal basis on which to establish area-based management measures BNJ.

\footnotetext{
${ }^{41}$ Id. Article 77. (4) Define sedentary species as "organisms which, at the harvestable stage, either are immobile on or under the seabed or are unable to move except in constant physical contact with the seabed or the subsoil".

${ }^{42}$ Id. Article 77.3.

${ }^{43}$ For example in LOSC articles 79.2, 79.5, 80, 208, 210 and 216. See. MOSSOP, J., "Protecting Marine Biodiversity on the Continental Shelf beyond 200 nautical miles", Ocean Development and the International Law, vol.38, 2007, pp. 284, 287- 289.

44 "As long as any restriction on freedom of the high sea is demonstrably connected to the goal of exercising sovereign rights over resources, the coastal state is justified in taking action.” Id. p.299.

45 ROTHWELL D., and STEPHENS, T., The International Law of the Sea, Hart Publishing, Oxfort/Portland/Oregon, 2010, pp. 99, 109-111. Also see LOSC Article 76.8.

${ }^{46}$ SALPIN CH. and GERMANI, V., "Marine Protected Areas beyond National Jurisdiction: What's Mine is Mine and What you Think is yours is also Mine" in Review of European Community \& International Environmental Law (RECIEL), 19, 2, 2010, p. 179.
} 


\subsection{The Convention on Biological Diversity}

The Convention on Biological Diversity and LOSC are complementary instruments with respect to the conservation and sustainable use of marine biodiversity. ${ }^{47}$ In this regard, the Parties to the $\mathrm{CBD}$ are required to implement that Convention consistently with the rights and obligations of States under the law of the sea. ${ }^{48}$ This does not affect the Convention's applicability to the Continental Shelf unless the obligations under CBD conflict with LOSC obligations. ${ }^{49}$

With respect to $\mathrm{ABNJ}$, the provisions of the CBD apply only to processes and activities, regardless of where their effects occur. Thay are carried out under a Party's jurisdiction or control, ${ }^{50}$ and do not apply to the components of biodiversity per se. Nevertheless, the CBD's principle, as described in article 3, proclaims that States, inter alia, “(...) have the responsibility to ensure that activities within their control do not cause damage to the environment of areas beyond national jurisdiction". "For this reason, the CBD underlines the need for cooperation among Parties in respect of ABNJ for the conservation and sustainable use of biodiversity. ${ }^{52}$

This includes identifying and monitoring these processes and activities as well as conducting environmental impact assessments of proposed projects likely to have significant adverse impacts on biodiversity. ${ }^{53}$ Likewise, where necessary, guidelines for selecting, establishing and managing protected areas should be developed. ${ }^{54}$

In view of the CBD's activities on MPAs in practice, it seems that the CBD perceives that it has a role in developing scientific criteria for the selection of MPAs, and not, or not yet, for the actual designation of MPAs. ${ }^{55}$

\footnotetext{
${ }^{47} \mathrm{CDB}$, Articles 1 and 2.

${ }^{48}$ Id. Article 22.

${ }^{49}$ MOSSOP, J., "Protecting Marine ...", cit, p. 288.

${ }^{50} \mathrm{CBD}$, Article 4 (b).

${ }^{51} \mathrm{CBD}$, Article 3.

${ }^{52} I d$. Article 5.

${ }^{53}$ Id. Article 7 (a, b, c) and 14.1 (a-d). Explicitly recognized in decision VII/5, supra note 28 paragraph 56.

${ }^{54}$ Id. Articles 8. See. DRANKIER, P., "Marine Protected Areas in Areas beyond National Jurisdiction", The International Journal of Marine and Coastal Law, vol.27, 2012, pp. 296-297.

55 In the opinion of Petra Drankier "In recent years, CBD has been particularly active in developing scientific criteria for the identification of ecologically or biologically significant areas (EBSAs). It may be
} 


\subsection{Regional Seas Organizations and Mandates}

Since 1974 many of the regional arrangements have been initiated through the United Nations Environment Programme (UNEP) Regional Seas Programme, which now covers a total of 18 markedly different maritime regions. ${ }^{56}$

Some of the Regional Seas organizations have incorporated the LOSC duties into conventions, protocols and annexes setting forth a mandate and procedure for the establishment of regionally representative networks of MPAs, amongst other measures. The problem is that although there are many Regional Seas Programs, only five have an explicit mandate and jurisdictional areas that include ABNJ. Examples include the Barcelona Convention and its Protocol on Biodiversity and Specially Protected Areas; ${ }^{57}$ the Convention for the Conservation and Sustainable Use of the Wider Caribbean Region and its Protocol for Specially Protected Areas and Wildlife (SPAW Protocol) ${ }^{58}$ the Convention for the Protection of the Marine Environment and Coastal Areas of the South East Pacific ${ }^{59}$ and the OSPAR Convention ${ }^{60}$ and its Annex V "On the protection and conservation of the ecosystems and biological diversity of the Maritime Area." Finally, the Antarctic Treaty System and its Protocol on Environmental Protection contains a mandate for systems of MPAs and the Convention for the Conservation of Antarctic Marine Living Resources (CCAMLR) has a mandate for closed areas for conservation and scientific purposes. ${ }^{61}$

questioned whether the CBD would be the most appropriate forum in this respect in the future" Id., pp. 298 and 337.

56 UNEP, About Regional Seas, <http://www.unep.org/regionalseas/about/default.asp>, accessed $07 / 06 / 2012$

${ }^{57}$ Convention for the Protection of the Mediterranean Sea against Pollution, 16 February 1976, 1102 UNTS 27, amended in 1995 and renamed the Convention for the Protection of the Marine Environment and Coastal Region of the Mediterranean (hereinafter Barcelona Convention); Protocol concerning Mediterranean Specially Protected Areas, 10 June 1995, 2102 UNTS 203, 161, Art. 8.3 (hereinafter SPA/BD Protocol).

${ }^{58}$ Protocol Concerning Specially Protected Areas and Wildlife to the Convention for the Protection and Development of the Marine Environment of the Wider Caribbean Region (SPAW Protocol) 18 January 1990, 2180 UNTS, 103.

591981 Convention for the Protection of the Marine Environment and Coastal Areas of the South East Pacific 33 International Digest of Health Legislation (1982) 96 (Lima Convention).

${ }^{60}$ Convention for the Protection of the Marine Environment of the North-East Atlantic, Paris 22 September 1992, entered into force on 25 March 1998, 2354 UNTS 67, 32 ILM 1069 (hereinafter OSPAR Convention).

611959 Antarctic Treaty Washington DC, 1 December 1959, entered into force 23 June 1961, 402 UNTS 71 (1961).1991 Protocol on Environmental Protection to the Antarctic Treaty, Madrid, 4 October 1991, 30 ILM 1461 (1991). 
This general lack of an explicit mandate means that States in such organizations have been reluctant, or may not consider it a priority, to also deal with matters beyond their 200 nautical mile EEZs. ${ }^{62}$ It is important to note that even where regional organizations can designate and have designated MPAs in ABNJ, without extensive cooperation from the sectoral organizations responsible for managing fishing (RFMOs), for shipping activities (IMO) and for managing mineral resources in the area (International Seabed Authority, ISA), such MPAs may have no real protection, as they cannot secure compliance from non-parties to the regional agreement. ${ }^{63}$

\section{IMPLEMENTATION OF THE LEGAL INSTRUMENTS FOR ESTABLISHING MARINE PROTECTED AREAS BEYOND NATIONAL JURISDICTION - A CASE STUDY OF THE OSPAR CONVENTION}

In general the OSPAR Convention contains the main provisions of customary international law reflected in Part XII of LOSC as well as provisions from other global and regional agreements on conservation and the sustainable use of the marine environment: for example, the CBD, UNGA Resolution and Helsinki Convention. OSPAR's provisions are a precedent for future collaboration between global and regional organizations as they link environmental protection and cross sectoral responsibilities in the marine ABNJ jurisdiction, such as NEAFC, IMO and ISA. ${ }^{64}$

\section{The Convention for the Protection of the Marine Environment of the North-East}

\section{Atlantic (OSPAR Convention)}

The OSPAR Convention ${ }^{65}$ was adopted with the principal purpose of creating a quasicomprehensive regime for the protection of the marine environment of the North-East Atlantic. It replaced two preceding conventions: namely, the 1972 Oslo Convention for

62 GJERDE, K., and RULSKA-DOMINO A., Marine Protected Areas beyond National Jurisdiction: Some Practical Perspectives for Moving Ahead. The International Journal of Marine and Coastal Law Vol. 27, 2012, p.357.

${ }^{63}$ Id.

${ }^{64}$ OSPAR Commission (2012, 10 June). International Cooperation. Available at:

$<$ http://www.ospar.org/content/content.asp?menu=00060600000000_000000_000000OSPAR> accessed 10/06/2012.

${ }^{65}$ OSPAR Convention, cit. 
the Prevention of Pollution by Dumping from Ships and Aircraft (Oslo Dumping Convention) and the 1974 Paris Convention for the Prevention of Marine Pollution from Land Based Sources (Paris Convention). ${ }^{66}$

Consequently, the Parties to the OSPAR Convention are those of the Oslo and Paris Convention (Belgium, Denmark, European Union, Finland, France, Germany, Iceland, Ireland, Netherlands, Norway, Portugal, Spain, Sweden and the UK) and Luxembourg and Switzerland. ${ }^{67}$ The maritime areas include internal waters, territorial seas and the high seas of these Parties that are within the Atlantic and Arctic Oceans and their dependent waters ${ }^{68}$

To achieve the objective mentioned above, the Parties shall apply the precautionary principle. They are also obligated to take all possible steps to prevent and eliminate pollution and to protect the maritime area against the adverse effects of human activities. ${ }^{69}$ At present, the OSPAR programmes and measures for combating marine pollution are well advanced and the Commission ${ }^{70}$ has adopted five strategies for implementing the ecosystem approach in the whole area. ${ }^{71}$

At the same time in 1998 the Parties took a further step towards implementing an integrated environmental protection system for the North East Atlantic region with the adoption of Annex V to the Convention. ${ }^{72}$ Under their article 2, the Contracting Parties committed themselves, linked the obligations of the OSPAR Convention and the CBD to taking the necessary measures to protect and conserve the ecosystems and

\footnotetext{
66 TANAKA,Y., A Dual Approach to Ocean Governance: The Cases of Zonal and Integrated Management in International Law of the Sea, University of Westminster UK, ASHGATE, England/USA, 2008 , p. 149.

67 OSPAR Commission. (2012, 06 June). OSPAR Convention. Available online at : $<\mathrm{http}$ :/www.ospar.org/content/content.asp?menu=01481200000000_000000_000000>, $\quad$ accessed $06 / 06 / 2012$.

${ }^{68}$ OSPAR Convention, article 1 (a).

${ }^{69} I d$. article 2 (1.a); article 2 (2.a) and (b) and 2 (3.b).

${ }^{70}$ About the Commission and their duties, see OSPAR Convention article 10.

71 OSPAR Commission. (2012, 07 June). OSPAR Strategy. Available online: $<$ http://www.ospar.org/content/content.asp?menu=01491300000000_000000_000000>, accessed 07/06/2012.

72 The first meeting of the OSPAR Commission at Sintra Portugal in 1998 adopted Annex V to the OSPAR Convention, which entered into force on 30 August 2000: $<$ www.ospar.org/eng/html/convention/ospar_conv10.htm>, accessed 07/06/2012.
} 
biodiversity of the maritime area and adopoted joint programmes and measures of control for these purposes. ${ }^{73}$

Measures pertaining to the management of fisheries or maritime transport are excluded from the Commission's responsibilities. Nevertheless, when the Commission considers that action should be taken within the maritime area they refer the matter to the attention of the competent authority or international body. ${ }^{74}$

When issues of maritime transport are referred to the IMO, Contracting Parties to the OSPAR Convention, who are also member States of the IMO, must cooperate with the IMO so that an appropriate response is given. This includes the IMO approving regional or local action, taking into account the IMO's particularly sensitive sea area guidelines and MARPOL special areas guidelines. ${ }^{75}$

Besides Annex V, there have been two relevant recent developments within the OSPAR framework: namely, the Strategy on the Protection and Conservation of the Ecosystems and Biological Diversity, ${ }^{76}$ which has four objectives, one of the most important of which is the creation of an ecologically coherent network of well managed MPAs $\mathrm{BNJ} ;{ }^{77}$ and the Helsinki Commission (HELCOM) ${ }^{78}$ agreement in which the Contracting Parties expressed their support for the Declaration of the WSSD. ${ }^{79}$

In consequence, the OSPAR Contracting Parties entered into a commitment to establish a network of MPAs by 2010 (extended to 2012), consistent with the CBD target for effectively conserved marine and coastal ecological regions, which will: (a). Protect,

73 OSPAR Convention, article 2 and 3 of Annex V. See. TANAKA, Y., “A Dual Approach...” cit, pp.150- 152 .

${ }^{74}$ OSPAR Convention, article 4 and penultimate recital of Annex V.

${ }^{75} \mathrm{Id}$, article 4 (2) of Annex V.

76 The 2003 OSPAR Strategy on the protection and conservation of the Ecosystems and Biological Diversity of the Mritime Area was adopted in 1998. paras. 2.1 and 2.2. For more information see Ospar Commission (2012, 07 June) Quality Status Report 2010, table of international and regional framework for the protection and conservation of biodiversity. Available online at: $<$ http://qsr2010.ospar.org/en/ch10.html>, accessed 07/06/2012.

77 Strategy of the OSPAR Commission for the Protection of the Marine Environment of the North-East Atlantic 2010-2020, Part II, 3.1 (a,b,c,d), p. 7. Available online at: $<$ http://www.ospar.org/html_documents/ospar/html/10-03e_nea_environment_strategy.pdf\#BDC>, accessed 07/06/2012

78 The HELCOM Commission belongs to the 1992 Convention on the Protection of Marine Environment of the Baltic Sea (hereafter, Helsinki Convention).

${ }^{79}$ Meeting of the OSPAR Commission for the Protection of the Marine Environment of the North-East Atlantic, Bergen: 20-24 September 2010, Annex 49, paras. 1 and 26. 
conserve and restore species, habitats and ecological processes which have been adversely affected by human activities; (b). Prevent degradation of, and damage to, species habitats and ecological processes, following the precautionary principle; (c). Protect and conserve areas that best represent the range of species, habitats and ecological processes in the maritime area. ${ }^{80}$

\section{The designation of the OSPAR network of marine protected areas in the high} sea

Since the OSPAR Recommendation 2003/3, the OSPAR Commission has confirmed its general intention to consider the declaration of MPAs in the high sea, according to which the OSPAR network of MPAs could be areas reported by a Contracting Party together with any other area in the maritime area outside the jurisdiction of the Contracting Parties. ${ }^{81}$ With this in mind, a map of the OSPAR maritime area was prepared, as a spatial planning tool, indicating the ABNJ. ${ }^{82}$

Thus in 2008, France, Germany, the Netherlands and Portugal made a proposal to form a network of sites that covered representative areas of the Wider Atlantic. As a result, the OSPAR Commission agreed to establish the first MPA known as the Charlie Gibbs Fracture Zone (CGFZ MPA) of the Mid- Atlantic Ridge which was supposedly outside the jurisdiction of the Parties and was vulnerable to human activities. ${ }^{83}$ At this time

\footnotetext{
${ }^{80}$ Strategy of the OSPAR Commission 2010-2020, cit, pp. 7-8.

${ }^{81}$ OSPAR Recommendation 2003/3 on a Network of Marine Protected Areas (OSPAR 03/17/1-E, 2003), Annex 9, p 2. Available at $<$ http://www.ospar.org/documents/dbase/decrecs/recommendations/or0303e.doc accessed 10/06/2012>. See the series of documents relating to the establishment of the OSPAR network of MPA in the Annex 10 (Guidelines for the Identification and Selection of MPA in OSPAR) and annex 11 (Guidelines for management of MPA in OSPAR) of the same recommendation.

${ }^{82}$ VON NORDHEIM, H., et al., 2010 Status Report on the OSPAR Network of Marine Protected Areas (OSPAR Commission, 2011), pp. 16 and 20. Available online at: $<$ http://www.ospar.org/documents/dbase/publications/p00548_Status\%20report\%20MPAs.pdf >, accessed $10 / 06 / 2012$.

${ }^{83}$ A proposal made by the World Wildlife Fund (WWF) and the University of York in 2000 identified several MPAs in ABNJ (Charlie-Gibbs Fracture Zone/Mid-Atlantic Ridge, Reykjanes Ridge, MidAtlantic Ridge north of the Azores, Milne Seamount Complex, Altair Seamount, Antialtair Seamount, Josephine Seamount Complex) as potential OSPAR. Later, co-supported by the Netherlands in 2007 and then under the auspices of OSPAR's, an expert group on MPAs drafted a background document for a CGFZ MPA. This convinced more Contracting Parties to support the proposal in 2008. Summary Record of the Meeting of the OSPAR Commission, Brest, 23-27 June 2008 (OSPAR 08/24/1-E, 2008).
} 
OSPAR also agreed on a roadmap to set out considerations and steps to look for possible adoptions of MPAs in ABNJ in $2010 .^{84}$

One year later, the Commission saw substantial political commitment towards the establishment of the MPA and it welcomed the NEAFC recommendation to close the Middle Mid-Atlantic Ridge area and others to bottom fisheries until 2015 in order to protect the vulnerable marine ecosystem. This decision has been the primary protective mechanism for the OSPAR high seas MPAs. ${ }^{85}$

Meanwhile, in accordance with the roadmap, a formal memoranda of understanding was drafted between the OSPAR Commission and such organizations as IMO, ISA and NEAFC. It strengthened attempts to broker a prospective "collective arrangement", for the potential management of selected areas in $\mathrm{ABNJ}{ }^{86}$

At the February 2010 OSPAR meeting, the Ad Hoc Working Group on CGFZ MPA placed the final option on the table: it proposed to establish just the southern part of the MPA, excluding the area subject to the Icelandic submission to the $\operatorname{CLCS}^{87}$ and the high sea above it. This resulted in the designation of MPA Charlie Gibbs South. ${ }^{88}$

Finally, OSPAR ministers ${ }^{89}$ officially established the world's first network in the high seas, the aim of which was to protect and conserve the biodiversity and ecosystems of the superjacent waters of six representative areas that together covered $286,200 \mathrm{~km}^{2},{ }^{90}$ :

\footnotetext{
${ }^{84} I d$.

85 Summary Record of the Meeting of the OSPAR Commission, Brussels, 22-26 June 2009 (OSPAR 09/22/1-E, 2009). See. GJERDE, K., "Marine Protected Areas beyond ...” cit, pp.357-358.

${ }^{86}$ This process ultimately led to a significant political outcome with the first network of MPAs in the high seas. See. O'LEARY, B.C., et al., "The first network of marine protected areas (MPAs) in the high seas: The process, the challenges and where next", Marine Policy, 36, 2012, p.600.

${ }^{87}$ Commission on the Limits of the Continental Shelf (CLCS), Outer limits of the continental shelf beyond 200 nautical miles from the baselines: Submission by the Republic of Iceland. 29 April 2009. Available at:

$<\mathrm{http}: / /$ www.un.org/Depts/los/clcs_new/submissions_files/submission_isl_27_2009.htm> accessed 12/06/2012.

${ }^{88}$ Report of the Meeting of the Ad Hoc Working Group on the Charlie Gibbs Fracture Zone, London, 15 February 2010 (WG-Charlie 10/6/1-E, 15 February 2010). See SALPIN CH and GERMANI, V., "Marine Protected Areas..." cit, p. 181.

${ }^{89}$ OSPAR Ministerial Meeting, Bergen 22-24 September 2010, Annex 49, paras. 27-30.

${ }^{90}$ H. von Nordheim, T. Packeiser, 2010 Status Report on the OSPAR Network of Marine Protected Areas (OSPAR Commission, 2011), p.21
} 
namely, Charlie-Gibbs South MPA, ${ }^{91}$ and Milne Seamount Complex MPA ${ }^{92}$ (both entirely within $\mathrm{ABNJ}$ ); the Mid-Atlantic Ridge north of the Azores High Seas MPA; ${ }^{93}$ Altair Seamount High Seas MPA, ${ }^{94}$ Antialtair High Seas MPA, ${ }^{95}$ and Josephine Seamount Complex High Seas MPA. ${ }^{96}$

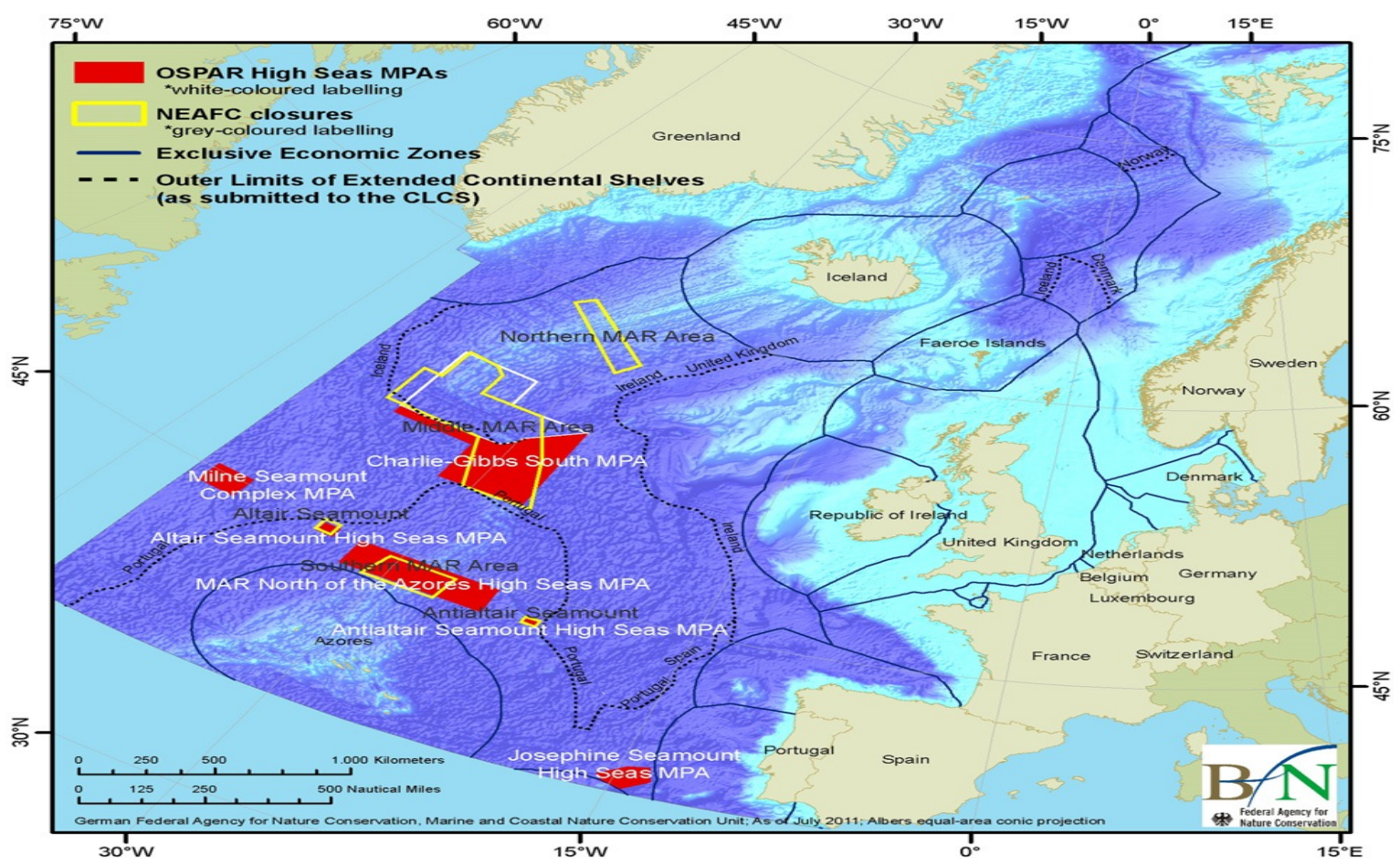

The last four MPAs encompassed a surface defined by the Portuguese submission on the establishment of the outer limits of its extended continental shelf. Nevertheless, OSPAR and Portugal worked together and agreed to develop common management strategies. ${ }^{97}$ In this political commitment these MPAs were recognized only to the extent that no prejudice was caused to "the sovereign rights and obligations of coastal

91 OSPAR Decision 2010/2 on the establishment of the Charlie-Gibbs South Marine Protected Area Bergen 22-24 September 2010 (OSPAR 10/23/1-E, Annex 36) in force 12 April 2011.

${ }^{92}$ OSPAR Decision 2010/1 on the establishment of the Milne Seamount Complex Marine Protected Area, (OSPAR 10/23/1-E, Annex 34) in force 12 April 2011.

93 OSPAR Decision 2010/6 on the Establishment of the MAR North of the Azores High Seas Marine Protected Area, (OSPAR 10/23/1-E, Annex 44) ) in force 12 April 2011.

94 OSPAR Decision 2010/3 on the establishment of the Altair Seamount High Seas Marine Protected Area, (OSPAR 10/23/1-E, Annex 38) in force 12 April 2011.

95 OSPAR Decision 2010/4 on the establishment of the Antialtair Seamount High Seas Marine Protected Area.(OSPAR 10/23/1-E, Annex 40) in force 12 April 2011.

${ }^{96}$ OSPAR Decision 2010/5 on the establishment of the Josephine Seamount High Seas Marine Protected Area (OSPAR 10/23/1-E, Annex 42) in force 12 April 2011.

${ }^{97}$ O'LEARY B.C., “The first ...” cit, p. 602-603. See also OSPAR Ministerial Meeting 2010, para. 28. 
States to the continental shelf, including their inherent right to delineate outer limits of the continental shelf in accordance with UNCLOS."98

In addition they stated that the respective frameworks of other competent authorities regulate for a number of current or future human activities occurring in those MPAs: in particular, fishing (NEAFC, International Commission for the Conservation of Atlantic Tunas, North Atlantic Salmon Conservation Organization, North Atlantic Marine Mammal Commission and International Whaling Commission), shipping (IMO), and extraction of mineral resources (ISA). ${ }^{99}$

In 2011 Portugal recognized the precautionary principle and its obligations under LOSC article 192 to protect and preserve the marine environment. It also expressed its intention to assume responsibility for taking measures for protecting the sea floor and sub-sea floor within these areas, even prior to the final conclusion of the CLCS. Upon invitation by Portugal, the OSPAR Commission agreed to collectively assume responsibility for taking measures for protecting the superjacent water column (the High Seas) in these areas. ${ }^{100}$

\section{FINAL CONSIDERATION}

I. It is feasible that effective MPAs can be established and implemented under a scheme of integrated protection. However, it requires an understanding of the relevant international and regional legal and policy framework. In particular, MPAs BNJ need to be established in the context of the specific legal and institutional framework.

II. At least at the regional level, Annex V to the OSPAR Convention and Biological Diversity and Ecosystems Strategy represent two comprehensive legal and policy instruments for implementing environmental protection and conservation BNJ. Nevertheless, the applicability of their measures to a third State in ABNJ is not clear. Neither is the mechanism for global endorsement (under the current LOSC) of environmental protection measures initiated at regional level.

\footnotetext{
${ }^{98}$ OSPAR Decision 2010/1 cit, p.2.

${ }^{99}$ Id.

100 OSPAR Ministerial Meeting, Bergen 22-24 September 2010, Annex 49, para 28. Also, OSPAR Decision 2010/3, cit, p.2.
} 
III. The designation of MPAs in ABNJ, within the framework of the OSPAR Convention, makes it clear that regional cooperation between the State Parties may be used to address the protection and preservation of the environment. This designation was made possible through the implementation of the provisions contained in LOSC (article 117, 192, in particular article 197, the sections 3 to 5 of Part XII), and in the CBD (article 5). In this regard, it will be particularly interesting to see how the coastal States concerned will exercise their sovereign rights and jurisdiction on the continental shelf, and balance those rights with their obligation to protect and preserve the marine environment.

IV. The global and regional sectoral organisations need to cooperate and be jointly managed if the marine biodiversity in ABNJ is to be conserved and sustainably used and the possible political gaps overcome. This cooperation and joint management could be improved by by drafting memoranda of understanding and joint programmes of work between and among sectoral and regional bodies. In this light, MPAs could be seen as a useful management tool to enhance the coordination between the leading management bodies (RFMOs, ISA, IMO, etc.) for specific geographical areas in need of protection, while also supporting compatible conservation objectives.

\section{BIBLIOGRAPHY}

ARDRON, JEFF, “Marine Spatial Planning in the High Sea”, Marine Policy, 32, 2008.

DRANKIER PETRA, "Marine Protected Areas in Areas beyond National Jurisdiction”, The International Journal of Marine and Coastal Law, vol.27, 2012.

GJERDE KRISTINA \& RULSKA-DOMINO ANNA, Marine Protected Areas beyond National Jurisdiction: Some Practical Perspectives for Moving Ahead. The International Journal of Marine and Coastal Law Vol. 27, 2012.

KIMBALL, LEE, "The International Legal Regime of the High Seas and the Seabed Beyond the Limits of National Jurisdiction and Options for Cooperation for the establishment of Marine Protected Areas in Marine Areas beyond the Limits of National Jurisdiction", Secretariat of the Convention on Biological Diversity, Montreal, Technical Series no. 19, 2005.

LONG, RONAN, "Review of the Legal Framework Applicable to Marine Protected Areas as a Tool for Ecosystem Conservation \& Fisheries Management", Review of 
MPAs for Ecosystem Conservation \& Fisheries Management, DIFRES, Copenhagen 2006.

MOSSOP, JOANNA, "Protecting Marine Biodiversity on the Continental Shelf beyond 200 nautical miles", Ocean Development and the international Law, vol.38, 2007.

O'LEARY, B.C., BROWN, R.L., \& OTHERS, “The first network of marine protected areas in the high seas: The process, the challenges and where next", Marine Policy, 36, 2012.

RAYFUSE, ROSEMARY \& WARNER ROBIN, "Securing a sustainable future for the oceans beyond national jurisdiction: the legal basis for an integrated cross- sectoral regime for the high seas governance for 21st century", The International Journal of Marine and coastal Law 23, 2008

LEARY DAVID, The Future of the International Environmental Law, United Nations University Press, Tokyo/NY/Paris, 2010

ROTHWELL DONALD \& STEPHENS TIM, The International Law of the Sea, Hart Publishing, Oxfort/Portland/Oregon, 2010

SALPIN CHARLOTTE \& GERMANI VALENTINA, "Marine Protected Areas beyond National Jurisdiction: What's Mine is Mine and What you Think is yours is al Mine" in Review of European Community \& International Environmental Law, 19, 2, 2010.

SCOVAZZI, TULLIO, "Marine protected areas on the high sea: some legal and policy considerations", International Journal of Marine and Coastal Law, vol. 19, No. 1, 2004.

TREVES TULLIO, "Regional Approaches to Protection of the Marine Environment" in Myron H. Nordquist and others, The Stockholm Declaration and the law of the Marine Environment, Kluwer Law International, The Hague, 2003.

WARNER ROBIN, Protecting the Ocean beyond National Jurisdiction: Strengthening the International Law Framework, Martinus Nijhoff, Leiden/Boston, 2009.

YOSHIFUMI TANAKA, A Dual Approach to Ocean Governance: The Cases of Zonal and Integrated Management in International Law of the Sea, University of Westminters UK, ASHGATE, England/USA, 2008. 